\title{
Outcomes of Urban Requalification under Neoliberalism: A critical appraisal of the SRU model
}

\section{Introduction}

In this chapter, we scrutinise the dimensions of discourse and sociocultural practice in order to examine the circumstances, means, and ends/impacts of the Urban Rehabilitation Societies' (SRU) institutional model of deliberation in the fields of housing and urban renewal in Porto and Lisbon. We draw on Fairclough and Fairclough's (2012) 'practical argumentation' framework to apply a Critical Discourse Analysis (CDA) approach to the formulation and implementation of the SRU model.

We aim to discuss how a context of crisis and austerity has provided a legitimate alibi for the inscription of neoliberal narratives, grounded in the virtues of the market, in the field of housing and urban renewal in Portugal, and how discourses and arguments related to housing and urban renewal led to the creation of new legal frameworks and institutions with the power to deliver entrepreneurial and discretionary models of urban renewal beyond existing state bureaucracies.

Specifically, the CDA conducted in this chapter is developed around the following research questions: 
(1) How has the SRU rehabilitation ${ }^{1}$ model shaped issues of affordable housing provision for low and middle-income families?

(2) How have political actors and practitioners with different roles defined and framed strategies and results regarding housing provision?

Our research used two main sources of information. On the one hand, documentary sources such as legislation and written policy texts, which were used to frame discourse analysis. On the other, the testimonies given in nine semi-structured interviews. These interviews (digitally recorded with the permission of each interviewee) were conducted with staff and officials working in Urban Rehabilitation Societies, in the municipalities of Lisbon and Porto and at the central institution responsible for housing policy in Portugal in $2015^{2}$.

The topic guide was made up of open questions and a loose structure, focusing on institutional models of urban requalification (the circumstances that justified their creation, means, practices), and the appraisal of the SRU model regarding its impacts on housing, urban

\footnotetext{
${ }^{1}$ In this paper we use the terms 'renewal', 'requalification', and 'rehabilitation' interchangeably, to describe actions that aim to improve the physical condition of buildings and infrastructures in order to adapt them to contemporary requirements or new uses. For the sake of clarity, in Portugal, whereas the concept of renewal (renovação) has been used to designate operations that involve partial or significant demolition of existing structures, requalification and rehabilitation (requalificação, reabilitação) refer to operations that do not involve the demolition of existing buildings, aiming at the maintenance of heritage buildings and landscapes.

${ }^{2}$ Instituto da Habitação e da Reabilitação Urbana (IHRU, Institut for Housing and Urban Rehabilitation).
} 
renewal, and social structure. The guide specifically addressed measures to provide affordable rental housing in-situ and to maintain less resourceful families in the city centres. The use of open questions and a loose structure allowed participants to voice their opinions, viewpoints and attitudes, which provided us with the basis for a Critical Discourse Analysis study. 


\section{Theoretical framework}

\section{a. Critical Discourse Analysis}

According to Marcuse (2015), effective and socially aware public policy research should interrogate the language used in urban policy and confront such language with issues of power, as language has important political implications, supporting the legitimacy of the status quo. Jacobs and Manzi (1996), Marston (2002), and Hastings (2000) claim that power in politics resides in the process whereby problems are constructed and articulated, since it is through language that we experience politics. The manner in which the problem is discursively represented is also important because it contains an explicit or implicit diagnosis as to what the problem is and how it should be addressed.

For example, growing literature on gentrification has revealed that capital-intensive urban redevelopment has increasingly been prosecuted, and sometimes initiated, by the state (van Gent \& Boterman, 2018), justifying the important role critical analysis of discursive practices plays in the fields of housing and urban rehabilitation policy.

Employed across a wide range of areas in the social sciences (cf. urban regeneration, housing policy etc.), CDA investigates discourse as a form of power: "systems of discourse are closely associated with ideology, hegemony and with the enactment and legitimation of power" (Marston 2002: 5). In the context of these studies, 'policy problems' are not seen as objective facts, but rather contested realities that need to be examined critically. Therefore, CDA 
provides a basis on which to challenge the concept of 'objectivity', particularly as it is used in bureaucratic discourses that have the power to create, maintain, and reinforce inequality, as well as hegemonic constructions of 'housing realities' (Saugeres 1999).

The so-called 'CDA group' of authors focuses primarily on how power relations are exercised and negotiated in discourse. Analysis shows how power relations are maintained/changed, by revealing connections between language, power, and ideology. In CDA, ideology has been used to describe the way that ideas and the values that comprise them reflect particular interests on the part of the powerful (Machin \& Mayr, 2012: 25).

Norman Fairclough (2013), one of the founders of CDA, developed an approach to discourse analysis that can be readily utilised for the purposes of empirical research/inquiry. Specifically, in their book 'Political discourse analysis', Fairclough and Fairclough (2012) provide conceptual tools for the analysis of practical argumentation in the context of political discourses (means-ends argumentation, cf. we should do A to achieve $\mathrm{X}$, and the argument used).

As Isabela and Norman Fairclough explain, practical argumentation is often characterised by complex chains, not only of means and ends (goals) but of goals and circumstances (Fairclough and Fairclough, 2012), and is associated with specific strategies. Using CDA, researchers should, therefore, scrutinise the circumstances, means, and results of local actors who operate in specific political and social contexts, often related to processes of institutional change and evolving institutional practices. 


\section{b. National context}

The 1970s is described by Konzelman et al. (2018) as a decade of economic instability and industrial unrest in Europe, leading to the reversal of post-war Keynesian economics and politics. It represents the end of the Keynesian consensus between capital and labour that allowed in most western and central European countries continuous government investment in education, social welfare, housing etc.

The 1970s was, however, very different in Portugal. In April 1974, a revolution put an end to a dictatorial regime that ruled the country for 41 years (1933-1974), with disappointing results in terms of wages, education, life expectancy, and housing conditions (Alves, 2015,2017 ), initiating a period of higher government spending on welfare programmes. The political shift occurred, however, in a very adverse macroeconomic and ideological period, characterised by, on the one hand, the shift from the previous consensus (of post-war Keynesian politics) to a neoliberal context of strong confidence in the market. And on the other, rapid population growth, associated with high immigration rates related to the influx of thousands of war refugees from the ex-colonies of Mozambique and Angola. In a context of high levels of poverty and weak state intervention, lowincome families had to rely on self-building or an illegal market to have access to a house which led to the expansion of informal settlements. Problems of housing shortages and affordability increased in the 1980s in most urban areas.

In the 1990s, following Portugal's accession to the European Economic Community (in 1986), the country saw a cycle of continuous growth and low unemployment rates (4\%) that was cited by a decade of centre-right governments to promote homeownership. 
In a context of low interest rates, the housing sector, as emphasised by Tulumello et al. (2018), was conceived as "a productive sector". Disproportionate government investment in subsidised loans/mortgages and tax deductions led to an increasing rate of owner occupation that in 2011 peaked at $73 \%$.

A decade later, the worldwide economic and financial crisis of 2008 led Portugal to an economic recession involving the loss of jobs and a reduction in purchasing power. In 2013, the unemployment rate reached a peak of $16.2 \%$. Several banks collapsed, families lost their homes, and the government had to borrow from abroad. Given dependence on foreign financing and a high national deficit, the implementation of austerity policies deepened the economic crisis, which led to further poverty and inequality. Traces of a Mediterranean welfare regime characterised by strong fragmentation of social protection in terms of programmes and beneficiaries (namely between protected insiders in permanent employment versus jobless unprotected outsiders) were reinforced by the political and economic austerity that followed.

With investors and public officials treating housing as a commodity (produced, sold and managed for private profit) cycles of investment in the built environment became to be primarily driven by financial rather than use-value reasons - an investment to accumulate wealth (Marcuse 2015: 191).

At the local level, a shift was observed in the role of local government from the basic function of regulating and managing the production of housing and the built environment (Sorensen, 2018), to an entrepreneurial role in which public officials seemed determined to attract footloose capital and an affluent middle class 
increasingly interested in central locations. The high proportion of social and private rented housing in inner areas, associated with low rents, derelict dwellings, and families working in the low-paid service jobs, make these areas increasingly vulnerable to neoliberal narratives that in a context of crisis and austerity emphasise the virtues of the market.

\section{c. Methodology}

In this section we present a critical appraisal of Urban Rehabilitation Societies (SRU) implementation in Lisbon and Porto, based on the CDA framework used in Fairclough and Fairclough (2012) and interviews, that were conducted with SRU staff and officials, local administration staff and officials, and counterparts in the central administration.

Initially structured as a primary source of information to complement documentary data on urban requalification policy, these interviews aimed to clarify the views of representatives and technical staff involved in the projects implemented by Lisbon and Porto Urban Rehabilitation Societies. The nine interviews were conducted with: members of staff and officials working in SRUs (5); the local municipalities of Lisbon and Porto (2), and the central institution responsible for housing policy (2). The guide we used for the interviews consisted of open questions and a loose structure to give participants the opportunity to voice their opinions, viewpoints, and attitudes. It was structured around two main groups of questions: (1) The efficacy of institutional models of urban requalification in terms 
of housing outcomes (prices, tenure, occupation) and their impacts on social structure; (2) The SRU model - role, targets/strategies (in terms of area, social-based, aims etc.), housing outcomes (prices, tenure, occupation), and its impacts on social structure. It specifically addressed measures to provide affordable rental housing in-situ and maintain less resourceful families in central areas. All interviews were conducted face-to-face and digitally recorded with the permission of interviewees. They were subsequently anonymised, transcribed, and codified. 


\section{The Urban Rehabilitation Societies model: an empirical application of Critical Discourse Analysis}

\section{a. The background of SRU implementation in Lisbon and Porto}

In this section we present a critical appraisal of Urban Rehabilitation Societies (SRU) implementation in Lisbon and Porto, based on the Critical Discourse Analysis (CDA) framework used in Fairclough and Fairclough (2012) and interviews focusing on the values, goals, and circumstances of different political and technical actors involved.

The SRU model was first formulated by central government legislation in 2004 as a tool to boost urban requalification in city centres facing a long-lasting decline in population and grave problems of building and infrastructure degradation. According to census data, between 1981 and 2001 the municipality of Lisbon lost approximately 330,000 inhabitants, and the municipality of Porto 90,000 , that is, around $30 \%$ of their residents. As for the built stock, $19 \%$ of all buildings were vacant in 2011 in Porto and $16 \%$ in Lisbon.

In Porto and Lisbon, according to the 2011 Census, the rental sector represents $44 \%$ and $42 \%$ of housing respectively, a share that is substantially higher than the national average (20\%). Considerable stock of housing characterised by old contracts and low rents are the result of decades of rent control and public disinvestment. Poor housing conditions typically accommodate sitting tenants with low 
economic resources, who are therefore more exposed to displacement due to rent increases.

Given a climate of economic crisis and austerity, the creation of SRUs was allegedly justified to promote greater efficiency and cutbacks in public bureaucracy. Representing a new institutional arrangement, SRUs were created as publicly-owned companies. ${ }^{3} \mathrm{~A}$ large range of powers and competencies, such as contracting loans, setting urban and housing strategies, licensing private operations, expropriating or forcing the sale of buildings, were transferred from local municipalities to the Urban Rehabilitation Societies. The nonprofit corporate status of the SRU model made it easier to employ staff, contract commercial loans, and to implement faster licensing procedures, allegedly improving the cost effectiveness of urban rehabilitation by the private sector.

SRU rehabilitation operations required framing by strategic documents approved by SRU administrations and the municipality and could be implemented either directly by SRUs or in association with partners (within the frame of specific contracts). It was envisaged that SRUs would work in close cooperation with municipalities and the central state to promote rehabilitation in the so-called 'Urban Rehabilitation Areas' (ARU in the Portuguese acronym), but with substantial freedom to define their strategy of action.

\footnotetext{
${ }^{3}$ Ownership could be exclusively by the local municipality (as was the case in Lisbon), or through a partnership between the municipality and central state via the Institute of Housing and Urban Rehabilitation (the model adopted by Porto Vivo SRU).
} 
Subsequent revisions of SRU legislation (in 2009 and 2012) and the effects of the financial and economic crisis reinforced thismodel as an opportunity for market-led operations in housing due to strong restrictions on public funding for such operations and, on the other hand, limitations on commercial banking loans for public institutions. In practice, funding schemes for rehabilitation by private owners have been drastically reduced in recent years and replaced by tax reductions and benefits. Regarding the funding schemes available for SRUs specifically related to urban rehabilitation operations, the European Bank of Investment (EIB) has been one of the most relevant sources, followed by the Joint European Support for Sustainable Investment in City Areas programme (JESSICA) in the 2007-2013 period and smaller central government programmes managed by the IHRU (see Branco \& Alves, 2018 for further detail).

Both Porto and Lisbon were in the front line of the creation of SRUs, having set up their companies in 2004 , immediately following the publication of the legislation that created this model. In Lisbon, three Urban Rehabilitation Societies were created for small areas across the city, but only one of them - Lisboa Ocidental SRU - carried on a rehabilitation strategy while the other two were dismantled by the municipality in 2009. Located outside the core historic centre in a middle-class area near important national monuments built in the 16th and 19th centuries, the company is $100 \%$ owned by the municipality of Lisbon and had an intervention area representing around $1 \%$ of the municipality's area and around 1300 buildings. Until 2018, when the municipality extensively reviewed its intervention area and competencies, its activity focused on direct 
intervention in both public spaces and SRU/municipal buildings with a strong emphasis on promoting rehabilitation by owners, who are predominantly local residents or small-scale investors, and almost exclusively funded by EIB loans.

Porto Vivo SRU is jointly owned, $60 \%$ belonging to the central state (through IHRU) and $40 \%$ by the municipality of Porto. The historic centre rehabilitation area, the main territory of intervention, is a world heritage site located in the city centre of approximately $5 \mathrm{sq}$ $\mathrm{km}-12.5 \%$ of the municipality's area - and 1800 buildings. The overall strategy of Porto Vivo SRU was defined in 2005 in the Masterplan of Porto Vivo SRU (Porto Vivo SRU and Câmara Municipal do Porto, 2005) and was implemented through a mix of approaches consisting of small-scale (quarter) strategic documents, urban rehabilitation contracts with private partners or real estate funds, direct rehabilitation of derelict buildings owned by the SRU, and integrated public space operations (the latter two funded by national and structural pots).

\section{b. Critical Discourse Analysis of Urban Rehabilitation Societies' implementation in Lisbon and Porto}

As mentioned, we use Fairclough and Fairclough's practical argumentation framework for the CDA of the SRU model. The approach to practical argumentation developed in Fairclough and Fairclough (2012) is a normative one, that is, arguments are evaluated as well as analysed. They can be critically evaluated on several grounds. For example, against evidence of the consequences that pursuing a specific line of action will have on stated goals or 
other goals, against evidence that there are other better means than those advocated for achieving the goals, or against the biased way existing states of affairs are represented, interpreted. or 'problematised' (the circumstantial premise) (for more details. see Fairclough \& Fairclough 2015).

Figure 1 presents the practical argumentation structure developed by Fairclough and Fairclough which conceptualises actors' choices of action. The figure illustrates the meaning and connections between the concepts used by the authors, who have extended CDA methodologies in order to incorporate them in the description of practical reasoning concerns that are central to our case study.

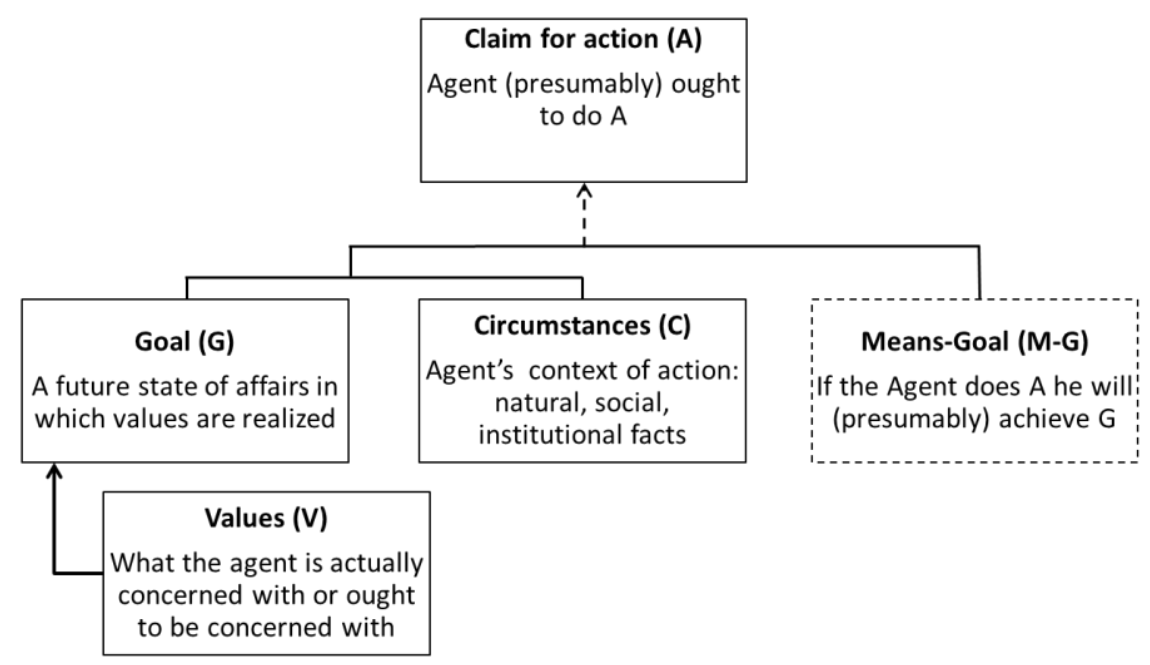

Figure 1 - Structure of practical argumentation (Fairclough \& Fairclough, 2012: 45) 
Existing states of affairs are represented in the Circumstantial premise, possible and desirable alternative future states of affairs are represented in the Goal premise. Goals are shaped by both internal reasons (related to values) and external reasons (such as duties and obligations), and they do not necessarily represent agents' wishes regarding choices or courses of action. This acknowledges that actors are constrained by the political, institutional, and economic circumstances of their work contexts. As for Means, these correspond to actions that will lead the agent from a current set of circumstances to an envisaged state of affairs. The Means-Goal premise has a conditional form: if a course of action A is pursued, it will (or is likely) to take us from the existing state of affairs $C$ to the desirable future one $\mathrm{G}$ in accordance with values $\mathrm{V}$.

The practical claim advocates pursuing a particular course of action. Taking the means to the goal $\mathrm{G}$ (performing action A) is, allegedly, the solution to the problem identified in the Circumstantial premise.

\section{c. Analysis of the interviews}

For the purposes of this analysis, the data collected from the interviews was analysed according to three groups of interviewees: (A) staff and officials working in the SRU; (B) staff and officials working in the local municipalities of Lisbon and Porto, and (C) staff and officials working in the central institution responsible for housing policy. In Annex 2, we present a selection of quotations that illustrate their individual viewpoints in the frame of each component of the structure. 
Table 1 presents in a systematised way the results of the interviews for the Means-Goal premise by groups of interviewees. The analysis has enabled us to identify similarities in the answers of different groups of interviewees regarding the 'values' and 'circumstances' components, demonstrating that there is a certain consensus among actors from different institutions involved in the formulation and implementation of the SRU model.

On the one hand, there is a common or similar framing in the circumstantial premise, that a world and national economic crisis demanded a context of austerity associated with cutbacks in public spending, requiring a new approach to urban renewal and housing. Moreover, the idea that previous decades of urban rehabilitation policy in Portugal had been ineffective and costly, and that a new approach was needed, was used to support a different claim for action, one centred in the mobilisation of private investment as the key driver of rehabilitation.

The argumentation developed by the interviewees reveal the dominance of economic efficiency as a driving concern. Interviewees emphasised the prevailing idea that the new urban renewal model should be cost-efficient, while values of social cohesion and sustainability were only mentioned secondarily and only by groups B and C. It has been argued that neoliberal policies are in fact ideology-driven (Konzelman et al., 2018) and that the government's real goal is to legitimise policies that are driven by private rather than public interests; looking at Table 1, it is possible to observe the overall presence of neoliberal ideas and approaches, centred on the claim that public actions should focus on public spaces and supporting investment by private actors. 
At the central government, broader concerns are apparent in the definition of actions. There is a strong commitment to the devolution of competencies but also great concern for financial sustainability, while the strategies and operations formulated and implemented on the ground should promote economic growth. At the local and national levels, there is a common discourse that the processes of gentrification, related to processes of urban renewal/requalification are necessary for the redevelopment of historic centres of cities such as Porto, without however problematising who will ultimately benefit.

\begin{tabular}{|l|l|l|l|}
\hline \multicolumn{1}{|c|}{ Group } & \multicolumn{1}{|c|}{ Goals } & \multicolumn{1}{c|}{ Means-Goals } & \multicolumn{1}{c|}{$\begin{array}{c}\text { Claim for } \\
\text { Action }\end{array}$} \\
\hline (A) SRU & $\begin{array}{l}\text { Intervention } \\
\text { area with } \\
\text { requalified } \\
\text { housing and } \\
\text { high-quality } \\
\text { urban spaces. }\end{array}$ & $\begin{array}{l}\text { Pursue the } \\
\text { requalification } \\
\text { of public spaces } \\
\text { and public } \\
\text { buildings and } \\
\text { support private } \\
\text { investors to } \\
\text { maximise } \\
\text { requalification. }\end{array}$ & $\begin{array}{l}\text { We aim to } \\
\text { renovate } \\
\text { public } \\
\text { space/owned } \\
\text { buildings and } \\
\text { induce private } \\
\text { investment in } \\
\text { requalification. }\end{array}$ \\
\hline $\begin{array}{l}\text { (B) Local } \\
\text { administration }\end{array}$ & $\begin{array}{l}\text { Intervention } \\
\text { area with } \\
\text { requalified } \\
\text { housing and } \\
\text { high-quality } \\
\text { urban spaces. } \\
\text { Protected }\end{array}$ & $\begin{array}{l}\text { Pursue the } \\
\text { requalification } \\
\text { of public spaces } \\
\text { and public } \\
\text { buildings and } \\
\text { support private } \\
\text { investors to }\end{array}$ & $\begin{array}{l}\text { We aim to } \\
\text { renovate } \\
\text { public spaces } \\
\text { and owned } \\
\text { buildings and } \\
\text { induce private }\end{array}$ \\
\hline
\end{tabular}




\begin{tabular}{|l|l|l|l|}
\hline & $\begin{array}{l}\text { heritage and } \\
\text { city-scale } \\
\text { balanced } \\
\text { development. }\end{array}$ & $\begin{array}{l}\text { maximise } \\
\text { requalification, }\end{array}$ & $\begin{array}{l}\text { investment in } \\
\text { requalification. }\end{array}$ \\
\hline $\begin{array}{l}\text { (C) Central } \\
\text { administration }\end{array}$ & $\begin{array}{l}\text { Empowered } \\
\text { local } \\
\text { administration } \\
\text { and SRUs } \\
\text { effectively } \\
\text { implementing } \\
\text { urban } \\
\text { requalification } \\
\text { policies. }\end{array}$ & $\begin{array}{l}\text { Decentralise } \\
\text { policy } \\
\text { implementation } \\
\text { and provide } \\
\text { both an } \\
\text { adequate } \\
\text { institutional } \\
\text { framework and } \\
\text { incentives to } \\
\text { boost urban } \\
\text { requalification } \\
\text { while }\end{array}$ & $\begin{array}{l}\text { We need to } \\
\text { prevent city- } \\
\text { mobilising all } \\
\text { public and } \\
\text { private actors. }\end{array}$ \\
& & $\begin{array}{l}\text { controlling } \\
\text { public spending. }\end{array}$ & \\
& & & \\
& &
\end{tabular}

Table 1 - The formulation of Goals, Means-Goals, and the actions which were chosen and are supported by the actors' argumentation (Claim for Action).

The results of our research confirm Fairclough and Fairclough's claim that: "the selection of what counts as relevant circumstances are determined by the arguer's concerns and values" (Fairclough \& Fairclough, 2012: 47). Our research effectively confirms the central role of values for the interpretation of circumstances and possible courses of action. For example, when rehabilitation in the context of partnership contracts involved the reassignment of housing uses, 
priority was given to the facilitation of private investment by cutting back bureaucracy, the relocation of previous tenants in other areas, and other measures that enabled project implementation according to private actors' interests. In addition, it is interesting to recall that the neoliberal model was not imposed on the actors. In their discursive practices, actors claim to be convinced that the neoliberal model is the best solution for the physical rehabilitation of the built environment and claim that social issues are beyond their competence and must be resolved by other institutions (e.g. displacement/ relocation of existing tenants via social housing).

Argumentation in support of this line of action drew, on the one hand, upon a partial understanding of what the actors consider to be the values at stake in public intervention, leading institutions such as urban rehabilitation societies to prioritise efficiency and the physical and social upgrading of the areas over social concerns (social cohesion, social inclusion).

The dominant concern for all actors was financial constraints, not the social well-being of tenants or the maintenance of a social mix in central areas. The main determinant of choices was a circumstantial lack of public resources, but also the dominant view that a neoliberal model was more adequate to implement city centre rehabilitation, a policy shift that was seen as necessary and, for some actors, desirable.

In this new policy paradigm, the role of SRUs was seen to manage, coordinate, and facilitate investment, stepping back as a provider of funding in favour of private (and mainly commercial) investors. While economic concerns such as cost-efficiency and financial sustainability ranked high in the actors' priorities, social concerns 
were devalued, even though the context of social crisis associated with austerity policies was quite dramatic.

While rationales for action are similar among local actors, specificities were noted, deriving from their context of action, which was significantly different between Lisbon and Porto, with more conflicting views in the latter city, essentially due to the interpretation of the consequences of the SRU's actions. In concrete terms, disagreement over the extent to which the goal of financial sustainability was compromised by Porto Vivo SRU's renewal projects introduced a breach in argumentation supporting the involvement of private investors, which led local and central administration actors to incorporate accountability and public service values as concerns in their discourses (for more details, see Alves \& Branco 2018). 


\section{Conclusion}

Using Critical Discourse Analysis, a methodology for the analysis of policy discourse and policy making, in this paper we attempt to demonstrate how language shapes the definition of Goals, MeansGoals, and a Claim for Action, which shape the social production and practices of institutions. The importance of this becomes evident when we, after Fairclough and Fairclough (2012), claim that what distinguishes political discourse from other types of discourse is that it involves deliberation over what ought to be done in the context of divergent interests and values, scarcity of resources, uncertainty and risk.

From this perspective, using CDA to examine how desirable courses of action are framed helps us to understand not only the ideological setting in which a particular discourse is produced, but also why and for whom choices are made. This contributes to our ability to answer two fundamental questions: Who has the power in the city, and what they do with that power? (Hall, Hubbard, Short, 2008). Whereas new policy vocabulary attempts to legitimise specific programmes and approaches, critical theory, as Marcuse (2015) claims, should emphasise the disjuncture between the actual and the possible.

Whereas in our earlier paper (Branco \& Alves, 2018) we demonstrate that, following a phase characterised by more distributive policies aiming at pursuing equality, neoliberal ideology has become a dominant paradigm in Portugal in the field of urban renewal and housing, in the current paper we attempt to scrutinise in detail the practical arguments for why public officials have sought 
to justify pursuing a more market-orientated and market-dependent course of action.

What this research makes evident is that in the mind-set of public officials there is increasing separation between, on the one hand, the physical rehabilitation of historic centres through the renovation of buildings and public spaces to attract new population and uses, and on the other the 'social intervention' that public officials claim should be provided for a limited group of people with low incomes and through separated mechanisms (a social housing sector) that is residual in Portugal ${ }^{4}$.

Where once concerned with slum clearance and the improvement of housing conditions for existing low and middle-income population, housing and urban policies are currently concerned with improving conditions for markets to operate more efficiently and foster the economic growth of a narrow section of interests. The choice to support private investors rather than support the welfare of households raises concerns about the adverse effects of market-led interventions in terms of reinforcing inequalities between socioeconomic groups and residential enclaves within the city (cf. Alves, 2016).

The current phase of market-supportive neoliberalism (for more details, see Allmedinger 2016) in cities with increasing investment in tourism, while bearing a heritage of a poor working class and degraded buildings, has exposed sitting tenants to various forms of displacement, destroying the identity of historical centres related to

${ }^{4}$ For a critique of this approach, see Alves and Burgess (2018) 
their activities, the mixture of social classes, but also feeding real estate speculation, which has increased the value of housing and rents.

After a decade of SRU intervention, official statistics show that rents in the centres of Lisbon and Porto saw a period of rapid growth from 2015 onwards under pressure from foreign investment and tourism ${ }^{5}$, threatening the maintenance of a middle class and its traditionally mixed social identity.

To conclude, the results of our application of Critical Discourse Analysis confirm that, in a context of austerity policies this new institutional and policy phase has been driven by ideology. The creation of the Urban Rehabilitation Societies institutional framework and of legislation which deregulated rents enabled policy options for an urban rehabilitation model that favoured private sector interests at the expense of low and middle-class interests (Branco \& Alves, 2018). Furthermore, analysis of the discourse of actors working on the ground revealed that this neoliberal narrative was fully assimilated by the actors thus playing a decisive role in their choices of action.

In terms of the policy implications of our study, we would like to emphasise two general recommendations. First, that housing and rehabilitation policies should not support real-estate speculation, gentrification, and the displacement of tenants but should rather

\footnotetext{
${ }^{5}$ Between the first trimester of 2016 and the second trimester of 2018 the added variation in the median value per $\mathrm{m} 2$ of dwellings sales $(€)$ was $34 \%$ in Porto and 47\% in Lisbon (source: Estatisticas de preços da habitação ao nível local, Quarterly, available at www.ine.pt )
} 
focus on the eradication of poor housing and foster the maintenance of the authenticity and mixed social character of locations. Second, alternative modes of thinking and acting should be pursued. In this regard, there is a wealth of experience, in terms of taxation, subsidies, and price regulation (Whitehead \& Williams, 2018). In the planning field we recommend the implementation of 'inclusionary zoning' tools that require the inclusion of on-site affordable housing provision as part of general market developments and as a condition of planning approval. The underlying idea that the owner has no moral right to the full increase of land value that arises from planning decisions is generally accepted even in liberal countries (see Couch, 2016 for the case of England) where site-by-site negotiations attempt to secure the provision of cheap land for non-profit housing associations. 


\section{Bibliographic references}

Allmendiger, P. (2016). Neoliberal Spatial Governance. Routledge. Alves, S. (2015). Welfare State Changes and Outcomes: The Cases of Portugal and Denmark from a Comparative Perspective. Social Policy \& Administration, 49 (1), 1-23.

Alves, S. (2016). Spaces of inequality: It's not differentiation, it is inequality! A socio-spatial analysis of the City of Porto. Portuguese Journal of Social Science, 15 (3), 409-431.

Alves, S. (2017). Poles Apart? A Comparative Study of Housing Policies and Outcomes in Portugal and Denmark. Housing, Theory and Society, 34 (2), 221-248.

Alves, S., Branco, R. (2018). "With or without you: models of urban requalification under neoliberalism in Portugal". In Changing Societies: Legacies and Challenges. Vol. i. Ambiguous Inclusions: Inside Out, Inside In, Eds. S. Aboim, P. Granjo, A. Ramos, Imprensa de Ciências Sociais, 457-479.

Alves, S., Burgess, G. (2018). Planning policies and affordable housing: A cross-comparative analysis of Portugal, England and Denmark, International Conference on the Global Dynamics of Social Policy, University of Bremen, Germany - October 25th \& 26th.

Branco, R., Alves, S. (2018). Urban rehabilitation, governance, and housing affordability: lessons from Portugal. Urban Research and Practice, DOI:10.1080/17535069.2018.1510540

Couch, C. (2016). Urban Planning - An Introduction. Palgrave. 
Fairclough, N. (2013). Critical discourse analysis and critical policy studies. Critical Policy Studies, 7(2), 177-197, DOI: 10.1080/19460171.2013.798239

Fairclough, I., Fairclough, N. (2012). Political Discourse Analysis: A Method for Advanced Students. Routledge.

Fairclough, N., Fairclough, I. (2015). Textual Analysis In: Bevir, M., Rhodes, R. A. W. (Eds.) (2015). The Routledge Handbook of Interpretive Political Science. Routledge, 186-198.

Hall, T., Hubbard, P., Short, J. R. (eds.) (2008). The SAGE companion to the city. Sage.

Hastings, A. (2000). Discourse Analysis: What Does it Offer Housing Studies? Housing, Theory and Society, 17(3), 131-139.

Jacobs, K., Manzi, T. (1996). Discourse and policy change: The significance of language for housing research. Housing Studies, 11(4), 543-560.

Konzelmann, S. J., Deakin, S., Fovargue-Davies, M., Wilkinson, F. (2018). Labour, Finance \& Inequality: The Insecurity Cycle in British Public Policy, Routledge.

Machin, D., Mayr, A. (2012). How to Do Critical Discourse Analysis - A Multimodal Introduction. Sage Publications.

Marcuse, P. (2015). Depoliticizing urban discourse: How "we" write. Cities, 44, 152-156.

Marston, G. (2002). Critical Discourse Analysis and PolicyOrientated Housing Research. Housing, Theory and Society, 19(2), 82-91. 
Porto Vivo SRU, and Câmara Municipal do Porto (2005). Masterplan para a Revitalização Urbana e Social da Baixa do Porto. Accessed 15 May 2017, http://www. portovivosru.pt/pt/areade-atuacao/enquadramento

Saugeres, L. (1999). The Social Construction of Housing Management Discourse: Objectivity, Rationality and Everyday Practice. Housing, Theory and Society, 16(3), 93-105.

Sorensen, A. (2018). Institutions and urban space: Land, infrastructure, and governance in the production of urban property. Planning Theory \& Practice, 19 (1), 21-38.

Tulumello, S., Ferreira, A. C., Colombo, A., Di Giovanni, C., Allegra, M. (2018). Comparative planning and housing studies beyond taxonomy: A genealogy of the Special Programme for Rehousing (Portugal). Transactions of AESOP, 2, 32-46.

Van Gent, W., Boterman, W. (2018). Gentrification of the Changing State. Tijdschrift voor Economische en Sociale Geografie, DOI:10.1111/tesg.12331.

Whitehead, C., Williams, P. (2018). Assessing the evidence on Rent Control from an International Perspective. Accessed 2 December 2018, $\quad$ https://research.rla.org.uk/wp-content/uploads/LSEInternational-Evidence-on-Rent-Control-Report-2018-Final.pdf 


\section{Annex 1 - List of interviewees}

\begin{tabular}{|c|c|c|}
\hline Institution & Position & Roles \\
\hline Porto Vivo SRU & Senior officer & $\begin{array}{l}\text { Project implementation } \\
\text { Management }\end{array}$ \\
\hline Porto Vivo SRU & Technical staff & Project implementation \\
\hline Porto Vivo SRU & Administration & $\begin{array}{l}\text { Policymaking } \\
\text { Management }\end{array}$ \\
\hline Porto Municipality & Political staff & Policymaking \\
\hline IHRU (Central office) & Administration & $\begin{array}{l}\text { Policymaking } \\
\text { Management }\end{array}$ \\
\hline $\begin{array}{l}\text { IHRU (Porto } \\
\text { delegation) }\end{array}$ & Senior officer & Management \\
\hline $\begin{array}{l}\text { Lisboa Ocidental } \\
\text { SRU }\end{array}$ & Technical staff & $\begin{array}{l}\text { Project implementation } \\
\text { Management }\end{array}$ \\
\hline $\begin{array}{l}\text { Lisboa Ocidental } \\
\text { SRU }\end{array}$ & Administration & $\begin{array}{l}\text { Policymaking } \\
\text { Management }\end{array}$ \\
\hline Lisbon Municipality & Senior officer & $\begin{array}{l}\text { Project implementation } \\
\text { Management }\end{array}$ \\
\hline
\end{tabular}




\section{Annex 2 - Statements from interviewees according to practical argumentation premises}

Goals

Circumstances

Means-Goal
"There are companies dedicated to those tasks: social housing, social inclusion, dynamisation programmes. Not us: our goal is to rehabilitate. Rehabilitate the public space and rehabilitate the buildings" (Lisboa Ocidental SRU Administration)

"Those who are dedicated to making urban rehabilitation are the municipalities and it starts as a basic work which is [to rehabilitate] public space (...) cities are condominiums, and the municipality is their administration" (Porto Municipality - Political staff)

"At this moment, a notable blockage is shortage of funding." (IHRU - Central office)

"[the main blockages to urban rehabiliation are] the financial deficit of the country, if there was money available to push forward, to help, to make partnerships with private actors, all of this would move. There is no money." (Porto Vivo SRU - Senior officer)

"There was a conscience of the need for change. It was important to promote rehabilitation, to mobilise the owners, involve investors and even include international investors and, therefore, all that need for a change in strategy" (Porto Vivo SRU - Technical staff)

"the attraction of new residents is very important, because it rehabilitates patrimony and is an incentive to rehabilitate other occupied [buildings]" (Porto Vivo SRU Technical staff)

"Private actores are in command, firstly because they are more in number and secondly because they have more 
means to do it than public actors." (Porto Vivo SRU Senior officer)

"There is a change in our strategic alignement. We no longer have the financial means (...) there is a very importante role to be played by the SRU which is almost an investment agency. I am not talking about large projects, but small projects by small national or foreign investors" (Porto Vivo SRU - Administration)

Claim for Action

"Public space is the priority, because public space is what we do alone, private actors don't rehabilitate public space. It is up to the state to have a rehabilitated and wellmaintained public space [...] building rehabilitation should be residual and limited to what private actors don't do." (Lisboa Ocidental SRU - Administration)

"Incentivating urban rehabilitation is an absolutely fundamental strategy (...) this happens in a moment were financial means are scarce, municipalities are much more indebt and the central state has less means to support these operations (IHRU central office - Administration) 